\title{
Quantifying Cr(VI) production rates \\ as a function of manganese oxide mineralogy and dissolved organic carbon composition
}

\author{
F.O. BALOGUN ${ }^{1 *}$ AND M. L. POLIZZOTTO ${ }^{1}$
}

${ }^{1} 100$ Cascade Hall, Department of Earth Sciences, University of Oregon (*Correspondence: fbalogun@uoregon.edu)

Toxic chromium $(\mathrm{Cr})$ contamination of soils and water from anthropogenic and geogenic sources is a pervasive environmental and health issue. The toxicity of $\mathrm{Cr}$ is dependent on its interactions in the environment, particularly in redox transformations that convert $\mathrm{Cr}$ between benign $\mathrm{Cr}(\mathrm{III})$ to carcinogenic $\mathrm{Cr}(\mathrm{VI})$. Manganese $(\mathrm{Mn})$ oxides are ubiquitous soil minerals that facilitate $\mathrm{Cr}(\mathrm{III})$ oxidation $[1,2]$. However, in environmental systems, $\mathrm{Cr}$ availablity and reactivity are also dependent on the suite of structurally diverse natural dissolved organic carbon (DOC), which can limit $\mathrm{Cr}$ oxidation. These confounding factors make it difficult to assess the specific risks of $\mathrm{Cr}$ contamnation in natural systems.

The objectives of this research are to evaluate the rates of $\mathrm{Cr}(\mathrm{VI})$ production as a function of $\mathrm{Mn}$ oxides, DOC concentration and type and to investigate the role of DOC on reaction product speciation. Mixed batch experiments using synthesized $\mathrm{Cr}$ hydroxide, manganese oxide $(50 \mathrm{~nm})$, citric and/or salicylic acid are being conducted, with dissolved $\mathrm{Cr}(\mathrm{VI}), \mathrm{Mn}(\mathrm{II})$, total $\mathrm{Cr}$ and $\mathrm{Mn}$ quantified over time. Results are being used to quantify $\mathrm{Cr}(\mathrm{VI})$ production rates across DOC gradients of $0-10 \mathrm{mM}$.

Preliminary results at $\mathrm{pH}$ of 5 show that $\mathrm{Cr}(\mathrm{VI})$ production is a function of citric acid concentration. At starting concentrations of $0.5 \mathrm{mM}$, citric acid caused rapid $\mathrm{Cr}(\mathrm{VI})$ production, which peaked within 48 hours. However, within the same period, $10 \mathrm{mM}$ citric acid produced 7.5 times less $\mathrm{Cr}(\mathrm{VI})$. Ongoing work seeks to quantify reaction kinetics at $\mathrm{pH} 7$ and 9 and measure changes in DOC concentrations in concert with $\mathrm{Cr}$ redox processes. X-ray absorption spectroscopy data are being analyzed to determine speciation of $\mathrm{Cr}$ and $\mathrm{Mn}$ in solid-phase reaction products. These results will show the efficacy of DOC in limiting $\mathrm{Cr}$ oxidation and help better understand fate of $\mathrm{Cr}$ in multi-component systems.

\section{References}

[1] Pan et al. (2019). ACS Earth and Space Chemistry, 3(3), 357-365. [2] Oze et al. (2007). Proceedings of the National Academy of Sciences, 104(16), 6544-6549. 